\title{
Erratum
}

\section{Forces involved in length changes of cochlear outer hair cells}

\author{
Alfred H. Gitter ${ }^{1,2}$, Maximilian Rudert ${ }^{1}$, Hans-Peter Zenner ${ }^{1}$ \\ ${ }^{1}$ Sektion Physiologische Akustik, Klinik für Hals-Nasen-Ohrenheilkunde, Universität Tübingen, W-7400 Tübingen, Germany \\ ${ }^{2}$ Institut für Neuro- und Verhaltensbiologie, Westfälische Wilhelms-Universität, W-4400 Münster, Germany
}

Pflügers Arch (1993) 424:9-14

In the Abstract, lines 18-23 should have read:

"If the water permeability was taken into account, the compliance was probably around $500 \mathrm{~m} / \mathrm{N}$. Thus, a mechanism that changes the cell length by $1 \mu \mathrm{m}$ must generate a static force of at least around $2 \mathrm{nN}$ in an outer hair cell of the organ of Corti."

The last sentence of the Discussion should read:

"Mechanisms changing the cell length by $1 \mu \mathrm{m}$ must generate a force of at least $2 \mathrm{nN}$ in the outer hair cell of the organ of Corti." 